Seth Afikorah-Danquah, Research Officer

Department of Geography and Resource Development

University of Ghana

PO Box 59

Legon, Ghana

Fax: 23321500382

email: c/o akudzi@usaid.gov

Stream: $\quad$ Governance - Forestry

Discipline: Interdisciplinary

\title{
Local Resource Management in the Forest-Savanna Transition Zone: the Case of Wenchi District, Ghana
}

\section{Introduction}

In the forest-savanna transition zone of Ghana, environmental issues have long been a focus of policy attention. This paper examines interactions between people and vegetation change in the Wenchi area of Brong Ahafo region (Figure 1), part of the northern forest-savanna transition zone, in the context of both ecological and policy debates about the nature of environmental problems there.

Figure 1. Map of Ghana showing Wenchi district

Since early colonial times, the dominant view among scientists and administrators has been that human activities, such as farming, logging and bush fires, cause progressive savannisation of forests. In contrast, other, more recent views suggest that the forest-savanna boundary has remained relatively stable over historical times, and even that human activities can be associated with the formation of forests in savanna environments. While forestry policy has conventionally been based on removing local users' control over land and trees in favour of the State, recent policy discussions have focussed on the advantages of, and prospects for, forms of 'collaborative' forest management involving local communities.

This paper aims to contribute to these debates and to the forging of effective links between them, by specifying more precisely how particular human activities can be linked to particular patterns of environmental change. Applying the tools of environmental entitlements analysis to the cases of food cropping and woodfuel production in the study area, it examines how the participation of different social actors, shaped by particular institutional arrangements, can lead to contrasting ecological outcomes for forest-savanna dynamics. This, in turn, carries important implications for 
Ghana's recent forest policy moves which, while welcome, have sometimes been premised on overly static, homogeneous notions of 'community'.

Before proceeding to the case studies, some background discussion of ecology and society in the Wenchi area is necessary, as is an outline of the changes in Ghana's forest policy.

\section{Background}

\section{Social and ecological heterogeneity in the Wenchi area}

Wenchi is a strikingly heterogeneous district, both socio-culturally and linguistically, and ecologically. A variety of ethnic groups live within its borders. Apart from the majority Akanspeaking Brongs (generally considered as the land owners), there are the Hausa, Dagomba, Grunshi, Lobi-Dagarti and the Sissala who have migrated from the northern savanna regions. These groups not only speak different languages and are culturally diverse, but also practise different production regimes, varying by technology, crop and scale: ranging from small-scale subsistence to large-scale monocropping farming, and variously focussed on maize, yam, plantain, cocoyam, groundnuts, cowpea, pepper, tomato, eggplant, okro, onion, sorghum, pigeon pea, bambara beans, rice, tobacco and cotton. Other forms of social difference - by gender, age, position in the area's matrilineal kinship and political organisation, and so on - cross-cut linguistic differences, and are associated with a wide variety of livelihood strategies in which food cropping is combined with the collection and trade of non-timber forest and savanna products.

Ecologically, the southern part of the district largely comprises dry semi-deciduous forest, while the northern part consists of a mosaic of gallery forests and forest patches in more-or-less wooded savanna grassland. There is significant debate over the nature and dynamics of this type of forestsavanna boundary in West Africa. Many botanists and foresters - including those who influenced early forest policy in Ghana - believe that much of the area covered by savanna today would have been forested if it had been left undisturbed. Thus human activities, such as farming and bush fires, have been thought responsible for the 'savannisation' of forests (e.g. Swaine et al, 1976; Ramsay and Rose Innes, 1963). This view is in accordance with equilibrial, climax theories of vegetation change, seeing forest as the ultimate, stable end-point to which vegetation would progress in the absence of major disturbance. Such theories of derived savanna' lay behind the recommendation in Ghana by the colonial forester Thompson (1910) or forest legislation to establish forest reserves as a way of preventing what he assumed was the southward advance of the savanna. Of the dangers to the continued existence of forest, he gave first place to "the wasteful system of farming practised by the natives" which, in his view, was contributing to the loss of timber trees in particular and forests in general.

However recent studies in Ghana, informed by more recent ecological thinking, have come to question these derived savanna theories. Hall et al (1976), for example, have shown that the forest-savanna boundary has been stable during historical times and not retreated as earlier works had proposed. According to this study the boundary can be adequately explained in terms of a combination of rainfall, geology and relief; it is unnecessary to invoke differential population pressure and human impact (Hall et al, 1976). A similar study around Wenchi (Asare 1962) also 
maintains that the distribution of vegetation reflects variation in biotic and edaphic factors, with mixed forest, derived savanna and transition woodland usually occurring in a more or less definite pattern along slope catenas: forests occur more on summits, upper slopes and in river valleys, and savanna on upper and middle slopes and sometimes in valley bottoms. Transition woodlands, it is assumed, are associated with a developmental stage of transformation of savanna to forest when the former is left uncultivated and unburnt.

Furthermore, recent work has cast doubt on the assumption that farming always converts forest to savanna. In Côte d'Ivoire, Spichiger and Blanc-Pamard (1973) found, on the contrary, that farming in savanna adjacent to the boundary may favour the spread of forest species. In Guinea, Fairhead and Leach (1996) showed that farmers have been encouraging the formation of forest vegetation forms in savanna through settlement strategies and agricultural practices. There is historical evidence for this type of transformation in parts of Ghana (Fairhead and Leach forthcoming).

\section{Changes in Ghana's forest policy}

Despite these complexities associated with the analysis of vegetation change, older ecological theories, assuming farmers to be destructive of 'original' forest vegetation, have formed the basis of most policies regarding the use and management of forests in Ghana.

Table 1 gives an overview of the development of Ghana's forest policy. Forestry sector legislation goes back as far as 1906, when laws were passed to control the felling of commercial tree species. Following the creation of the Forest Department in 1908, many government-controlled forest reserves were selected and demarcated: by 1939 about 14,800 square kilometers of Ghana had been reserved. Acts such as the Forest Ordinance of 1911, which allowed the colonial governor to reserve all uninhabited forests, deprived local populations of previous user rights. While the 1948 Forest Policy claimed to give attention to the welfare of land users, in practice it strongly emphasised timber exploitation (Thompson, et al., 1995). In reserved forests, farmers were alienated not only from resources that they valued, but also from management decisions concerning them. Unsurprisingly, these reserve policies provoked considerable, and often successful, local resistance, and in this context the Forest Department found it difficult to ensure forest protection and to police 'encroachments' successfully. Forest policy also gave the State control over all supposedly 'natural' trees outside reserves, including those growing within farmer's fields. Nevertheless the government's focus on forest reserves is said to have promoted the uncontrolled exploitation for timber of off-reserve forests, contributing to their decline. 
Table 1. Overview of Ghana's Forest Policy

\begin{tabular}{|c|c|}
\hline 1908 & Creation of Forestry Department \\
\hline 1927 & $\begin{array}{l}\text { Enactment of Forest Ordinance } \\
\text { Principal statute governing the constitution and management } \\
\text { of forest reserves. } \\
\text { Vests in central government the power to constitute } \\
\text { reserves on all land for management by state. }\end{array}$ \\
\hline 1948 & $\frac{\text { Adoption of First Forest Policy }}{\text { Planned management introduced in reserve areas. }}$ \\
\hline 1962 & $\begin{array}{l}\text { The Concessions Act, (Act, 124) } \\
\text { Significantly modified the Forest Ordinance. The act } \\
\text { provides that all timber resources, together with all land declared to } \\
\text { be forest reserves or subject to timber concessions, are vested in the } \\
\text { state in trust for the communities concerned. The power to grant } \\
\text { timber concessions is vested in the Minister for Lands and Forestry. }\end{array}$ \\
\hline 1974 & $\begin{array}{l}\frac{\text { Forest Protection Decree }}{\text { Prohibited a range of activities within reserves }} \\
\quad \text { Forest user rights of stools and communities transferred } \\
\text { entirely to central govt. }\end{array}$ \\
\hline 1994 & $\begin{array}{l}\text { Forest and Wildlife Policy } \\
\text { Encouragement of community initiatives to protect natural } \\
\text { resources for traditional, domestic and economic purposes } \\
\text { Development of consultative and participatory mechanisms } \\
\text { to enhance land and tree tenure rights of farmers and ensure access } \\
\text { to local people to traditional use of natural resources }\end{array}$ \\
\hline
\end{tabular}

In view of these inadequacies of the 1948 policy, as well as in response to the expansion of Ghana's timber industry and concerns about the implications of tenure for forest resource 
management, steps have recently been taken to initiate a new forest policy. Among the proposals was the recognition of the possible advantages of participatory management of forests outside reserves by local people, and this is strongly emphasised in the current Forest and Wildlife Policy enacted in 1994. The Collaborative Forest Management Unit (CFMU) was established under the Planning Branch of the Forestry Department in 1992 with a mandate to develop a more participatory approach to forestry both on and off-reserves (CFMU 1993). One of the unit's main tasks is helping communities to develop their capacity to manage forest resources, and to explore possibilities for joint forest management systems involving both local communities and the Forest Department. At the same time, steps are being taken to transfer tenure of on-farm trees from the government to farmers.

These changes of policy emphasis are important. Nevertheless, as applied to the forest-savanna transition zone, they have not necessarily been informed by the shifts in ecological thinking outlined above. Furthermore, policy initiatives have frequently been framed by undifferentiated views of the 'communities' involved. While social difference and heterogeneity are frequently acknowledged by the agencies attempting to develop community-based approaches, no clear guidelines exist for how to translate this recognition into practical approaches. It is in such a context, this paper suggests, that the environmental entitlements approach might have value.

\section{THE WENCHI CASE STUDY}

The Wenchi case study aimed to gain a more specific understanding of how social differences in resource access, use and control, and the diverse, dynamic local institutions involved, shaped trajectories of environmental change in Ghana's forest-savanna transition zone, and to consider how such an understanding can help improve the practice of community-based sustainable development. Fieldwork spanning over nine months was carried out in two principal case study sites, Badu and Nchera. A number of sources of livelihood were investigated, but this paper limits discussions to food crop farming and charcoal production among different social actors.

\section{Food crop farming}

The significant differences between food cropping by landowners on one hand, and by immigrant settler-farmers on the other, highlight how different institutional arrangements for resource use can lead to contrasting ecological outcomes (Figure 2).

Figure 2. Environmental entitlements analysis: the case of farming by land owners and migrant tenant farmers

\section{$\underline{\text { Landowners }}$}

'Landowners' are the original, largely Brong-speaking Akan inhabitants of the Wenchi area. Both men and women landowners are involved in farming, but it is a common practice to find that most married women work on part of their husband's land. Divorced, widowed or single women can, however, operate their own farms. 
Rights over land are a fundamental endowment for food cropping. Whether through matrilineal inheritance, links to local chieftaincy, land markets or marriage, landowner-farmers generally have secure rights over land. According to oral tradition, land rights were 'originally' acquired either by conquest or by virtue of a group being the first to cultivate the land. Land has since been exchanged between chiefly lineages or stools by gift or purchase. In the past, land was regarded as communal property in Ghana, but the same cannot be said today. The exploitation of land now involves individual rights based on customary laws. Although by law government holds all land in Ghana in trust on behalf of the people, stools and traditional chiefs are regarded as the custodians of the land and are thus responsible for the allocation of land within their area of jurisdiction. The chief's subjects, through either the lineage or family, have rights of usufruct. Chieftaincy is therefore an important local institution in respect of land rights and this is recognized by government, as reflected in the share of royalties allocated to stools from timber or minerals that are exploited on the land.

Individuals, on the basis of membership of a family or lineage group, also have usufruct rights over communal, family or lineage land. Marriage is another important institution which can enable in-married spouses to have relatively secure access to land. Tenancy arrangements, including sharecropping, are other channels through which landless people, or those who do not have sufficient land, are able to gain rights of access over land. Others acquire land through land gifts.

Various formal and informal arrangements and negotiations are involved in the process of transforming endowments into alternative sets of benefits which are instrumental in achieving well-being. First, farmers need to mobilise labour to supplement their personal labour endowments. The gender division of labour at the household level is important in allocating tasks on the farm. The institution of nnoboa (co-operative work parties) is significant when particularly demanding agricultural tasks are to be undertaken. Those who cannot mobilise labour through these means - such as female farmers, frequently - may resort to hiring through the labour market, or to seeking help through informal kin and friendship networks.

Second are the combinations of knowledge, technology and more-or-less regularised practices through which landowners work their holdings. Landowner-farmers make use of both forest and savanna sites. On the former, they generally use a minimum tillage system of cultivation based on cutlass technology, and show a preference for long fallows. As Amanor (1993) argues, such practices, by leaving intact the seed stocks and root mats for forest tree species, generally allow the regeneration of forest fallows post-cultivation. On both forest and savanna sites, farmers also enrich their fallows, both by making deliberate efforts to leave certain trees standing, and sometimes by protecting sites from dry season fire. Planting of exotic tree species, notably Tectonia grandica, is also becoming popular among landowners, although this results in a more permanent conversion of the site from farm land to tree plantation.

These farming practices, in combination with customary tenure arrangements which give landowners incentives to engage in relatively long-term vegetation management strategies, have significant impacts on forest-savanna dynamics. In general, they allow for the persistence of forest or forest fallow on forest sites within the landscape mosaic, while on savanna sites, they 
sometimes promote increases in tree cover. However, the practice of leaving trees standing in fields has tended to be undermined by government legislation on tree tenure, which, by designating such trees as state-controlled, gives farmers little incentive to protect them.

\section{$\underline{\text { Immigrants }}$}

Immigrants constitute a large proportion of the population of the Wenchi area. Most are of northern Ghanaian origin, having settled as farmers. These stranger settlers, who are often referred to as Esirem fo or 'savanna people' by local landowners, farm under very different institutional arrangements from landowners, with different impacts on the landscape (cf. Amanor 1993).

Irrespective of the number of years a stranger has been settled in the area, he or she is still considered a stranger, holding low status in local kinship-based political organisation. This affects arrangements for acquiring land endowments. In the past, when land was generally communal, immigrants gained access to land relatively cheaply in the Brong Ahafo area by presenting drinks and a salutation fee to the chiefs. Thus the institution of chieftaincy determined to a great extent how much and what type of land should be allocated to stranger settlers. Immigrants now obtain rights of access to land through tenancy agreements, ranging from different types of sharecropping to leaseholds involving payments in cash. Many of these rights are short-term and relatively insecure. Furthermore, tenants' rights of access to trees and other non-timber resources are often restricted by the landowners.

Immigrant tenant farmers utilise the land for a variety of crops including yams, millet, maize, peas, sorghum, groundnuts and cassava, employing technologies which contrast with those of landowner-farmers. They generally prefer - and are frequently allocated - savanna woodland sites. During land preparation, many of the trees on the land are felled and stumped to make way for the creation of mounds, especially for yam cultivation. Farmers cultivate deeply using the hoe. Farmers also believe that crops tend to be less productive under shady conditions. Because of these practices, landowners have labeled immigrants as 'anti forest' or 'savanna people'. Tenants, like landowners, rely on their own and family labour, supplemented by the institution of nnoboa. Via the gender division of labour and usufruct rights to land gained through marriage, women tend to specialise in the cropping of groundnuts and peas on their husbands' land after the men have harvested the yams, using these crops for personal income.

By virtue of the fact that they depend on short-term leaseholds involving high tenancy fees, immigrant farmers frequently feel insecure in terms of land tenure. This has encouraged heavy short-term exploitation of the land (cf. Amanor 1993). The system of hoeing is also believed to be associated with deforestation and further destruction of the seed stock of trees and shrubs in the soil. Furthermore low land and tree tenure security discourages immigrant farmers from tending trees in their fields; neither do they make efforts to plant trees, in contrast to landowners. Hence immigrant's practices, it is believed, do not generally enhance forest vegetation cover. Indeed they can be associated with the savannisation of forest and fallow, reduction in tree cover in savannas, and, in some circumstances, with soil degradation. 


\section{Charcoal Production and Fuelwood Gathering}

Woodfuel, including firewood and charcoal, are the main sources of domestic energy for both rural and urban households in Wenchi district. Furthermore the savanna and forest-savanna transition zones of the Ashanti and Brong Ahafo Regions are major producing areas for the commercial charcoal trade which supplies Ghana's major urban centres.

Different social actors engage in these woodfuel-related activities in different ways. For domestic consumption, it is the responsibility of women, and particularly children, to gather and carry fuelwood. Charcoal production for commercial sale is dominated by the immigrant Sissala group. Individuals belonging to the stool families and other large landowners often engage in large-scale charcoal production, hiring the labour of so-called professional charcoal burners. Tobacco farmers also make use of large amounts of fuelwood in curing tobacco leaves.

Under current statutory law, all rights to trees and timber in Ghana are vested in the President in trust for the stools. Hence, in order to gain rights of access to trees, people are formally required to negotiate licences permits with the chiefs, the Forest Department and the District Assembly (Figure 3). However, this requirement is often ignored by fuel cutters, especially tobacco farmers, who instead cut wood on the basis of their usufruct rights to these lands. These competing bases for claims to trees fuel conflicts between tobacco farmers, charcoal producers, the Forest Department and landowners over the rights to natural trees in farms and over compensation for damaged crops.

Figure 3. Environmental entitlements analysis: the case of charcoal production

Transforming the endowment of rights to trees into legitimate effective command over woodfuel also requires labour. Intra-household arrangements and specialist co-operative work parties are effective in labour mobilisation for charcoal production. Market institutions are also important when charcoal is produced for commercial sale. The District Assembly has a certification scheme to regulate charcoal trading and transportation, while at the local level, this overlaps with various forms of informal market institution.

People involved in charcoal production and fuelwood gathering make selective use of tree species, from among a mixture of forest and savanna species. While domestic fuel collection generally uses dead wood and has little overall effect on tree cover, large-scale charcoal production is seen as a major driving force behind deforestation in this ecological zone. The extent to which felling for charcoal results in generalised deforestation, as opposed to a thinningout of preferred species, leaving other tree cover intact, depends partly on the quality of local vegetation. But in any case, the government makes little effort to check what it sees as illegal felling or to replace trees cut. Indeed, District Assemblies see this practice largely as a source of revenue generation through the issue of permits by the Forestry Department. Nor do charcoal producers or landowners respond to such de-wooding.

As already discussed in the context of food cropping, statutory law on land and tree tenure reduces people's interest in the management of tree saplings on farms. Customary land and tree 
tenure, in the form of unwritten laws or customary property rights, is in sharp conflict with government legislation and therefore tends to undermine the sustainable management of tree resources. Furthermore tree felling for charcoal - or indeed timber - currently gives farmers and landowners very little direct financial benefit from the royalty share channelled to stools and then to the people. In this context, there is little interest in replanting charcoal species, or in managing vegetation for sustained charcoal or timber production.

\section{Trajectories of environmental change}

The cases of food cropping and woodfuel production illustrate some of the diverse activities which support rural livelihoods in the Wenchi area, based on the use of natural resources. They show how the practices of different social actors with respect to a particular livelihood activity, as shaped by the institutional arrangements through which they obtain endowments and entitlements, can influence the environmental impact of that activity in highly significant ways. Hence it becomes misleading to discuss the 'impact of farming' on vegetation, for instance, without specifying who is farming, under what conditions of tenure, technology, labour and so on. In this respect, attention to social difference and to specific institutional arrangements can sharpen understandings of forest-savanna dynamics and their relationships with human activity. Current ecological debates, at a general level, highlight three possible trajectories of change in the forestsavanna transition zone. The Wenchi case suggests that all three types of dynamics highlighted in current ecological debates - conversion of forest to savanna, conversion of savanna to forest, and dynamic stability between these vegetation states - may be at work in different parts of the landscape, depending on the social actors and institutions influencing the site. Thus while landowner-farmers may be enriching fallows with trees in one place, engaging in afforestation practices through tree planting and deliberate nurturing of tree saplings on farms, tenants or charcoal cutters may be reducing tree cover or encouraging savannisation in another.

In shaping trajectories of environmental change, institutionally-conditioned practices also intersect with trends and contingencies in ecology. Thus Ghana's northern forest-savanna transition zone has, for instance, suffered a series of major dry season fires during the last few decades, with 1963 and 1983 notorious for their major fire events. In directly damaging forest vegetation and encouraging grass at the expense of trees, and in contributing to changes in the farming system particularly a switch away from fire-vulnerable cocoa and towards field crops such as maize, cultivated with savanna technologies - fire history has intersected with livelihood activities so as to further savannisation. Yet fire events, according to farmers, have also been significant in the spread of the rapacious creeper-like weed commonly known as Acheampong in the Wenchi area. Acheampong can, farmers say, suppress grasses and encourage the development of a thicket-like vegetation, thus encouraging a shift in the landscape from savanna to more woody vegetation forms.

The case study also highlights the problems in defining in a generalised way what trajectory of environmental change is desirable, or alternatively, constitutes 'degradation'. Different social actors benefit from, and would accord value to, quite different vegetation types. Thus the Forest Department has tended to give priority to forest, and to timber-rich, vegetation forms. Certain farmers value 'natural' forest and forest fallows for agriculture. But others - immigrants from the 
north and charcoal producers among them - gain benefits from savanna vegetation. And those who stand to benefit from teak plantations might favour large-scale landscape conversion to this type of use. These contrasting positions fuel conflicts - even within the villages of Wenchi around notions of who is 'environmentally friendly' and who is not. While some traditional authorities have responded to the supposed destruction of the resources that their people's livelihoods depend on - local responses which have been viewed very positively by practitioners in community-based sustainable development in Ghana - it is not clear that the 'environmental good' such institutions aim for is always so collective.

\section{Participation and institutions in highly differentiated communities}

The case study also demonstrates, then, why a simplistic view of community is inappropriate. Environmental use and management in the Wenchi area takes place within highly differentiated communities, in interaction with local and national government, as well as international actors such as development donors. These different social actors rely on different institutions to support their claims; institutions which are not only dynamic but often in conflict with each other. For instance, people engaged in tree felling for charcoal may be opposed to farmers wishing to enrich their fallows. Approaches to community-based sustainable development must therefore seek to resolve conflicts of interest among these different groups.

Nevertheless, a starting point for greater 'community participation' in forest management, and for intra-community negotiation to proceed, must be to establish an institutional framework in which local social actors have incentives for resource management and conservation. Currently, there is significant conflict between customary tenure arrangements and government legislation over tree tenure. People without some form of tenure security, as illustrated by the case of the immigrant tenant farmers, have little incentive for long-term environmental management. Reducing such conflicts will require reforms to the formal legal framework of access to and rights over forest resources, to ensure benefits to local people. It is encouraging that discussion of such reforms in Ghana is well underway.

\section{Conclusions}

The Wenchi examples have examined a number of resource management strategies in Ghana's forest-savanna transition zone using the environmental entitlements framework. Broadly, they have shown how components of heterogeneous environments become endowments and entitlements for different social actors. Attention has been paid to the diverse and dynamic formal and informal institutions which shape people's practices and attitudes in resource use and management, with particular ecological outcomes. Yet these diverse institutions have generally been ignored within the moves towards community forestry and collaborative forest management in Ghana. The case study also underscores the importance of a particular institution - tenure - in understanding resource management. It is only through secure rights to a given resource, and secure control over the benefits from it, that individuals and groups may be encouraged to undertake long-term investments in environmental management or enrichment. In sum, the case highlights the need to strengthen local institutions that will respond to people's needs for 
livelihood security, and to strengthen local claims-making capacity in relation to the institutions of the State.

\section{References}

Amanor, K.S. 1993 Wenchi Farmer Training Project: Social/Environmental Baseline Study ODA Assignment.

Asare, E.O. 1962, 'A note on the vegetation of the transition zone of the Tain basin in Ghana' Ghana J. Sci. 2, 60-73

CFMU 1993 A strategy for the development of collaborative forest management in the high forest zone of Ghana Planning Branch, Forestry Department, Kumasi

Fairhead, J. and Leach, M. 1996, Misreading the African Landscape: Society and Ecology in a Forest-Savanna Mosaic, Cambridge and New York: Cambridge University Press

Fairhead, J. and M. Leach, forthcoming, Rethinking Deforestation: global analyses and local realities: studies in West Africa. London: Routledge.

Hall, J.B., Swaine, M.D. \& Lock, J.M. 1976. "The forest Savanna boundary in west-central Ghana". Ghana J. Science 16:35-62.

Ramsay, J.M. and Rose Innes, R. 1963, "Some quantitative observation on the effects of fire on the Guinea Savanna vegetation of Northern Ghana over a period of eleven years" African Soils, $8,41-85$

Spichiger, R. and Blanc-Pamard, C. 1973 'Recherches sur le contact foret-savane en Cote d'Ivoire: Etude du recru forestier sur des parcelles cultivees en lisiere d'un ilot forestier dans le sud du pays baoule', Candollea, 28, 21-37.

Swaine M.D., Hall, J.B. and Lock, J.M. 1976 'The Forest-Savanna Boundary in West Central Ghana' Ghana Journal of Science, 16 (1) 35-52

Thompson, H.N. 1910, Gold Coast: Report on Forests. Colonial Reports Miscell. 66: 1-238.

Thompson et al 1995 Ecology of forest trees in Ghana ODA Forest Ecology and training project 1991-95 Final report. 